\title{
Quality attributes of chilled vacuum-packaged cold-smoked common carp (Cyprinus carpio) and cold-smoked bighead carp (Hypophthalmichthys nobilis) fillets
}

\author{
Milan Petar Milijašević, Jelena Arandjel Babić, Danijela Vojislav Vranić, \\ Branka Ranko Borović, Slavica Mirko Vesković Moračanin \\ Institute of Meat Hygiene and Technology, Belgrade, Serbia
}

Received June 28, 2015

Accepted May 2, 2016

\begin{abstract}
The aim of this research was to study the effect of vacuum packaging on selected microbiological, chemical and sensory properties of cold-smoked common carp (Cyprinus carpio) and cold-smoked bighead carp (Hypophthalmichthys nobilis) fillets stored at $3 \pm 0.5{ }^{\circ} \mathrm{C}$, and to determine the shelf life of the products. Fillets were analysed on days 1, 7, 10,12, 14, 15 and 16. The total viable count was significantly higher $(P<0.01)$ in common carp samples than in bighead carp samples from storage day 12. At the end of experiment, the numbers of TVC in both groups of samples had not reached the value of $7 \log \mathrm{cfu} / \mathrm{g}$. No significant differences $(P>0.05)$ were determined between the psychrotrophic viable counts in common carp and bighead carp samples during the whole period of storage. In cold-smoked bighead carp samples, lactic acid bacteria were the dominant micro-organisms at the end of storage period. Listeria monocytogenes and Salmonella spp. were not detected in any of the examined samples. The $\mathrm{pH}$ values in both samples groups were quite stable and ranged from $5.97 \pm 0.08$ to $6.18 \pm 0.07$ in cold-smoked common carp, and from $5.80 \pm 0.08$ to $5.98 \pm 0.06$ in bighead carp samples. The total volatile basic nitrogen concentration increased during the storage period in both groups of samples. Based on sensory evaluation, it was concluded that vacuum-packaged cold-smoked common carp samples remained acceptable up to 15 days of storage, whereas vacuum-packaged cold-smoked bighead carp samples remained unchanged until the end of the experiment.
\end{abstract}

Shelf life, microbiological indicators, chemical properties, sensory assessment

Most of the wild fish and fish from aquaculture consumed in Serbia are marketed for human consumption as fresh or frozen. However, smoked products have seen a considerable surge in popularity. Smoking is one of most acceptable fish-processing method, because it does not require expensive equipment, the production period is short, acceptability on the Serbian market is very good, considering that the local population is accustomed to eat mostly smoked pork. Cold-smoked fish is a very popular product; depending on different fish species, salt quantity and temperature treatment, additional heat treatment may be applied.

The quality of smoked fish depends on many factors, which are divided in two main groups: (1) production factors (nutrition, environmental conditions, genetic factors, sex and sexual maturity, life cycle) (Hovda et al. 2007), and (2) processing factors (slaughter, curing, smoking, and packaging) (Sikorski and Kolodziejska 2002).

Modern consumers demand high quality food that retains the sensory characteristics and nutritive value of the raw material from which it is produced; also, it is expected to satisfy very demanding safety standards. This requirement is largely met by packaging the products in vacuum or modified atmosphere. Development of materials and methods of packaging is a permanent process in modern science, contributing to the improvement of packaging efficiency. However, the basic packaging principles remain the same: to avoid contamination, to delay spoilage, to allow an enzyme reaction that improves the softness, to reduce the loss of weight, and to ensure retaining the sensory characteristics of products

Address for correspondence:

Milan Milijašević

Sector for Development and Technologies Transfer

Institute of Meat Hygiene and Technology

Kaćanskog 13, 11000 Belgrade, Serbia

\author{
Phone: +381112650655 \\ Fax: +381 112651825 \\ E-mail: milan.milijasevic@gmail.com \\ http://actavet.vfu.cz/
}


as much as possible (Murcia et al. 2003; Kerry et al. 2006). It has been confirmed that the packaging of smoked fish in vacuum significantly extends the shelf life of the product. On the other hand, if not manufactured and handled correctly, these products can also support the growth of pathogenic bacteria. That may pose a Listeria monocytogenes, Salmonella, Staphylococcus aureus and Clostridium botulinum risk for public health (ICMSF 1998).

Cyprinid species (common carp, bighead carp, and grass carp) are most commonly bred in Serbia. The aim of this research was to monitor changes of selected microbiological, chemical and sensory properties of vacuum-packaged cold-smoked common carp (Cyprinus carpio) and cold-smoked bighead carp (Hypophthalmichthys nobilis) fillets during storage at $3 \pm 0.5^{\circ} \mathrm{C}$ and to determine the shelf life of the products.

\section{Materials and Methods}

Sampling

Samples from eleven common carp and eleven bighead carp of $2.5 \pm 0.3 \mathrm{~kg}$ and $2.7 \pm 0.5 \mathrm{~kg}$ live weight, respectively, were obtained from a fishpond where a semi-intensive rearing system was used. Fish were processed at freshwater fish processing plant using a standard procedure (killing by electrocution, descaling, evisceration, and filleting). Two fillets from each carp were made, and each fillet was divided into 4 portions, i.e. a total of 8 portions were obtained from $1 \mathrm{fish}$. After primary treatment, fish were washed and soaked in brine for $24 \mathrm{~h}$ and then pressed, laid on the grid in chambers for $1 \mathrm{~h}$ at $20^{\circ} \mathrm{C}$. Smoking was performed on an automated smokehouse for $8 \mathrm{~h}$ at the temperature of $28^{\circ} \mathrm{C}$.

The 84 portions of cold-smoked common carp as well as the 84 portions of cold-smoked bighead carp were vacuum-packaged using the machine Variovac (Variovac Primus, Zarrentin, Germany), and a polyethylene-polyamide film (Suomen Union Verpackungs, Helsinki, Finland) with an oxygen permeability of $29-45 \mathrm{ml} \mathrm{O}, / \mathrm{m}^{2} / 24 \mathrm{~h} / \mathrm{atm}\left(23{ }^{\circ} \mathrm{C}, 50 \%\right.$ relative humidity, $\left.\mathrm{RH}\right)$ and a water vapour permeability of $10-15 \mathrm{~g} / \mathrm{m}^{2} / 24 \mathrm{~h}\left(38^{\circ} \mathrm{C}, 90 \% \mathrm{RH}\right)(1 \mathrm{~atm}=101325 \mathrm{~Pa})$. All samples were stored under the same conditions, at the temperature of $3 \pm 0.5^{\circ} \mathrm{C}$, and on days $1,7,10,12,14,15$, and 16 of storage, microbiological, chemical and sensory tests were performed.

\section{Microbiological analyses}

Fish fillets ( $25 \mathrm{~g}$ ) were homogenized in $225 \mathrm{ml}$ of MRD (Oxoid, Great Britain) in a stomacher (AES; Comburg, France) for $90 \mathrm{~s}$. Serial dilutions (10-fold) of fish homogenate were spread onto the surface of the appropriate dried media in Petri dishes for enumeration of the total viable count (TVC) and psychrotrophic viable count (PVC) on plate count agar (PCA, Merck, Germany), incubated at $30{ }^{\circ} \mathrm{C}$ for 3 days and at $4{ }^{\circ} \mathrm{C}$ for 5 days (respectively); Lactic acid bacteria (LAB) on de Man Rogosa Sharpe Agar (MRS) (Oxoid, Great Britain) incubated at $30{ }^{\circ} \mathrm{C}$ for 2 days under microaerophilic conditions; total yeast and mould count (TYMC) on Dichloran Rose-Bengal Chloramphenicol Agar (DRBC) (Merck, Germany) incubated at $25^{\circ} \mathrm{C}$ for 5 days. All plates were examined visually for typical colony types and morphological characteristics associated with each growth medium. Microbiological data were transformed into logarithms of the number of colony-forming units $\log \mathrm{cfu} / \mathrm{g}$.

The presence of Listeria spp. was determined by ISO 11290-1,2. Twenty-five g of fish fillets were homogenized with $225 \mathrm{ml}$ of sterile Fraser broth base (Biolife, Italy) in a stomacher for $2 \mathrm{~min}$. The homogenates were incubated at $20^{\circ} \mathrm{C}$ for $1 \mathrm{~h}$ to resuscitate stressed microorganisms. For the enumeration of L. monocytogenes, a volume of $0.1 \mathrm{ml}$ from each homogenate was directly streaked onto each of 2 Palcam Agar (Oxoid, UK) plates and incubated at $37^{\circ} \mathrm{C}$ for $24-48 \mathrm{~h}$. The homogenates were then supplemented by Fraser half selective supplement (primary enrichment) (Biolife) and incubated at $30^{\circ} \mathrm{C}$ for $24 \mathrm{~h}$ for detection of $L$. monocytogenes. Afterwards, $0.1 \mathrm{~mL}$ of the primary enrichment was inoculated in $10 \mathrm{~mL}$ of Fraser broth supplemented (Biolife) by Fraser selective supplement (secondary enrichment) (Biolife) and incubated at $37{ }^{\circ} \mathrm{C}$ for $24 \mathrm{~h}$. Cultures were streaked onto Oxford (Oxoid, UK ) plates and incubated at $30^{\circ} \mathrm{C}$. From each plate of the primary and secondary enrichment, 5 colonies presumed to be Listeria spp. were streaked onto TSYEA (Tryptone Soya Yeast Extract Agar) plates (Biolife, Italy) and incubated for $24 \mathrm{~h}$ at $37^{\circ} \mathrm{C}$. Colonies were selected for typical appearance on TSYEA and submitted to Gram staining, catalase and oxidase tests. Haemolytic activity and CAMP tests on sheep blood agar were performed for L. monocytogenes confirmation.

Determination of the presence of Salmonella spp. was performed according to ISO 6579. Briefly, $25 \mathrm{~g}$ of fish fillets were aseptically placed into a sterile stomacher bag with a filter that contained $225 \mathrm{ml}$ of buffered peptone water (BPW) (Biomeriéux, France) and were incubated for $18 \mathrm{~h}$ at $37^{\circ} \mathrm{C}$ after homogenization by hand massage from the outer surface of the bag for $2 \mathrm{~min}$. After pre-enrichment, 0.1 and $1 \mathrm{ml}$ of the BPW culture were transferred into Rappaport Vassiliadis Soya Peptone Broth (RVS) (Oxoid, UK) and into Muller-Kauffmann Tetrathionate-novobiocin Broth (MKTTn) (Oxoid, UK), respectively, and these were incubated for $24 \mathrm{~h}$ for primary enrichment at $37^{\circ} \mathrm{C}$ and $41.5^{\circ} \mathrm{C}$, respectively. After incubation, $20 \mu \mathrm{l}$ of these cultures were plated onto Chrom ID Salmonella (Biomeriéux, France) and Xylose Lysine Deoxycholate Agar (XLD) (Oxoid, UK). The absence of typical colonies for Salmonella on plates examined after incubation for $24 \mathrm{~h}$ at $37{ }^{\circ} \mathrm{C}$ indicated that the samples were Salmonella-free. 


\section{Chemical analysis}

Muscle $\mathrm{pH}$ was measured by Cyber Scan pH-510 digital pH-meter (EUTECH Instruments, Netherland).

The total volatile basic nitrogen (TVB-N) was determined using official steam distillation method according to Commission Regulation (EC) 2074/2005 and was expressed as mg TVB-N/100 g.

\section{Sensory evaluation}

The sensory evaluation was performed by six trained panellists prior to the chemical analyses. The samples were evaluated for overall acceptability, with regard to odour, flesh colour, and texture using $1-5$ intensity scale, with 5 corresponding to the most liked sample, and 1 corresponding to the least liked sample. The product was defined as unacceptable with a score of less than 2 points recorded by at least of $50 \%$ of the judges.

\section{Statistical analysis}

The mean values and standard deviations were calculated by using column statistics with the processing of 6 values for each analysed group. Significant differences between groups were calculated using one-way ANOVA analysis by Tukey comparative test in the program Microsoft Office Excel (2007). Differences were evaluated as significant at $P<0.05$.

\section{Results}

Figures 1 and 2 show the effect of storage on the growth rate of the total viable count, psychrotrophic viable count, lactic acid bacteria count and the total yeast and mould count in portions of cold-smoked common carp fillets and cold-smoked bighead carp fillets.

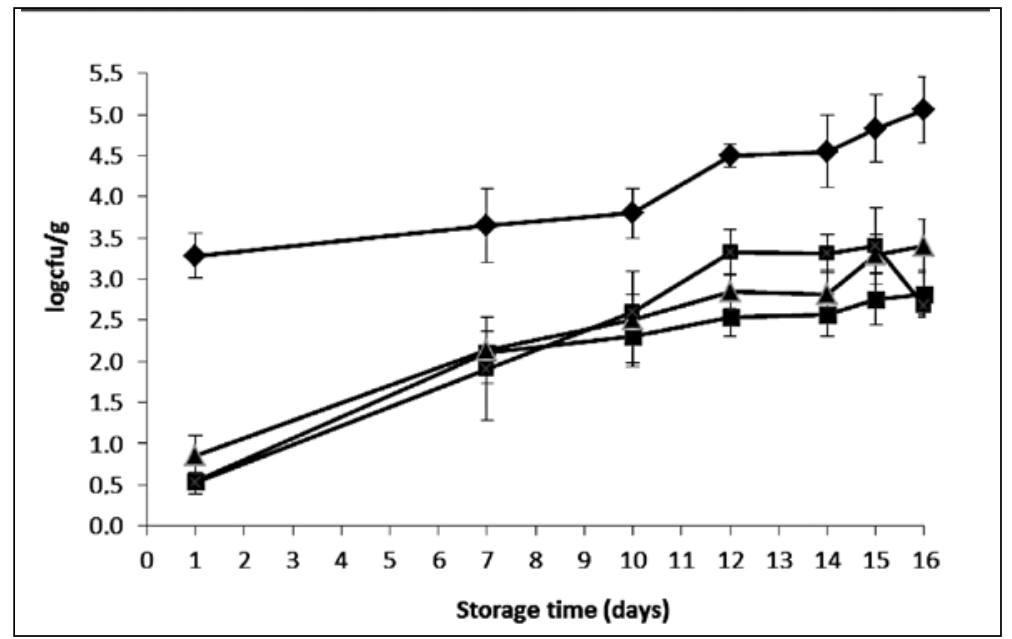

Fig. 1. Changes in the total viable count $(\bullet)$, psychrotrophic viable count $(\boldsymbol{\square})$, lactic acid bacteria $(\boldsymbol{\Delta})$ and total yeast and mould count $(\times)$ in cold-smoked common carp fillets during vacuum storage at $+3 \pm 0.5^{\circ} \mathrm{C}$.

The initial TVC values of common carp (3.28 $\pm 0.27 \log \mathrm{cfu} / \mathrm{g})$ and bighead carp samples $(3.06 \pm 0.43 \log \mathrm{cfu} / \mathrm{g})$ indicate high fish quality and good manufacturing practices. An increase in the TVC values through the storage period was observed in both groups of samples. The TVC values in common carp and bighead carp samples after 16 days of storage were $5.06 \pm 0.40 \log \mathrm{cfu} / \mathrm{g}$ and $4.10 \pm 0.64 \log \mathrm{cfu} / \mathrm{g}$, respectively. From storage day 12 the microbial growth of TVC was highly significantly $(P<0.01)$ more intensive in common carp samples than in bighead carp samples.

Psychrotropic viable counts were initially low in common carp samples $(0.56 \pm 0.10 \log \mathrm{cfu} / \mathrm{g})$ as well as in bighead carp samples $(0.65 \pm 0.07 \log \mathrm{cfu} / \mathrm{g})$. From storage day 1 until storage day 7, PVC values in both groups of samples were increased highly significantly $(P<0.01)$. In bighead carp samples $P V C$ values increased significantly $(P<0.05)$ 


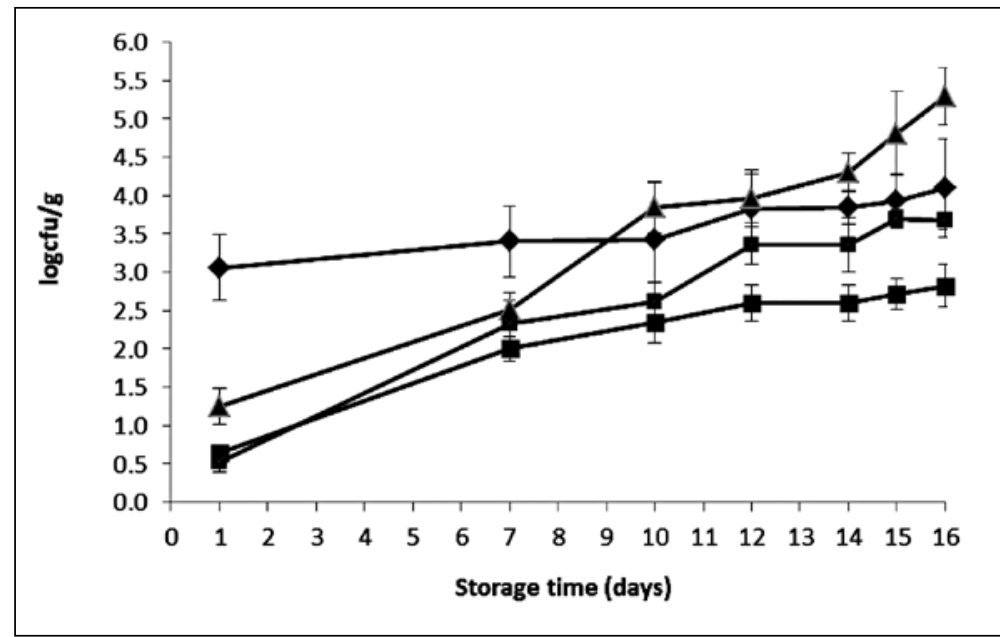

Fig. 2. Changes in total viable count $(\diamond)$, psychrotrophic viable count ( $\mathbf{\square})$, lactic acid bacteria $(\boldsymbol{\Delta})$ and total yeast and mould count $(\times)$ in cold-smoked bighead carp fillets during vacuum storage at $+3 \pm 0.5^{\circ} \mathrm{C}$.

from day 7 until day 10. No significant differences $(P>0.05)$ were determined between PVC values in common carp and bighead carp samples during the whole storage period.

At the beginning of storage, the LAB counts were $0.85 \pm 0.25 \log \mathrm{cfu} / \mathrm{g}$ in common carp samples and $1.25 \pm 0.23 \log \mathrm{cfu} / \mathrm{g}$ in bighead carp samples, gradually increasing until day $16(3.40 \pm 0.32 \log \mathrm{cfu} / \mathrm{g}$ and $5.30 \pm 0.37 \log \mathrm{cfu} / \mathrm{g}$, respectively). During the experiment, LAB values determined in bighead carp samples were significantly higher $(P<0.01)$ compared to LAB values determined in common carp samples.

The initial TYMC values were $0.52 \pm 0.13 \mathrm{log} \mathrm{cfu} / \mathrm{g}$ in common carp samples, and $0.54 \pm 0.35 \log \mathrm{cfu} / \mathrm{g}$ in bighead carp samples. From day 1 to day 12 TYMC values in common carp samples increased highly significantly $(P<0.01)(3.33 \pm 0.27 \log \mathrm{cfu} / \mathrm{g})$ and on the last day of experiment, TYMC values showed a significant decrease $(P<0.05)$ $(2.68 \pm 0.12 \log \mathrm{cfu} / \mathrm{g})$. Highly significant $(P<0.01)$ increases of TYMC values in bighead carp samples were found between storage days 1 and 7 , and days 10 and 12. The contents of yeast and mould in bighead carp samples at the end of the storage period were $3.67 \pm 0.11 \log \mathrm{cfu} / \mathrm{g}$. A highly significant difference $(P<0.01)$ between TYMC values of common carp and bighead carp samples was determined on storage day 16 .

Listeria monocytogenes and Salmonella spp. were not detected in any of the cold-smoked common carp fillets and cold-smoked bighead carp fillets during the whole storage period.

Figure 3 shows $\mathrm{pH}$ values in portions of cold-smoked common carp fillets and coldsmoked bighead carp fillets in dependence of the length of the storage period. In common carp samples the $\mathrm{pH}$ values decreased significantly $(P<0.05)$ from storage day $1(6.04$ $\pm 0.01)$ to day $7(6.01 \pm 0.02)$. Highly significant $(P<0.01)$ increases of $\mathrm{pH}$ values were observed from day $14(6.00 \pm 0.03)$ until day $16(6.18 \pm 0.17)$. In bighead carp samples the increase of $\mathrm{pH}$ value on day $7(5.98 \pm 0.24)$ was not significant. From then on, $\mathrm{pH}$ began to decrease and reached $5.80 \pm 0.13$ on storage day 16 . Compared to common carp samples, bighead carp samples had lower $\mathrm{pH}$ throughout the whole storage period, and on day 16 of the experiment that difference was highly significant $(P<0.01)$.

Figure 4 gives TVB-N values $(\mathrm{mg} / 100 \mathrm{~g})$ in portions of cold-smoked common carp fillets and cold-smoked bighead carp fillets in dependence of the length of the storage period. In common carp and bighead carp samples an increase of TVB-N values was observed. From storage day $14(21.52 \pm 1.40 \mathrm{mg} / 100 \mathrm{~g})$ till day $16(26.62 \pm 0.64 \mathrm{mg} / 100 \mathrm{~g})$, a highly 
significant $(P<0.01)$ increase of TVB-N values was determined in common carp samples. In bighead carp samples, a significant increase of TVB-N concentration $(P<0.05)$ was found between storage days $7(22.96 \pm 1.48 \mathrm{mg} / 100 \mathrm{~g})$ and $10(24.92 \pm 0.61 \mathrm{mg} / 100 \mathrm{~g})$, whereas highly significantly increases $(P<0.01)$ were determined from storage day 10 till the end of experiment $(28.38 \pm 0.18 \mathrm{mg} / 100 \mathrm{~g})$. Throughout the storage period common carp samples contained less TVB-N in $\mathrm{mg} / 100 \mathrm{~g}(P<0.01)$ than bighead carp samples.

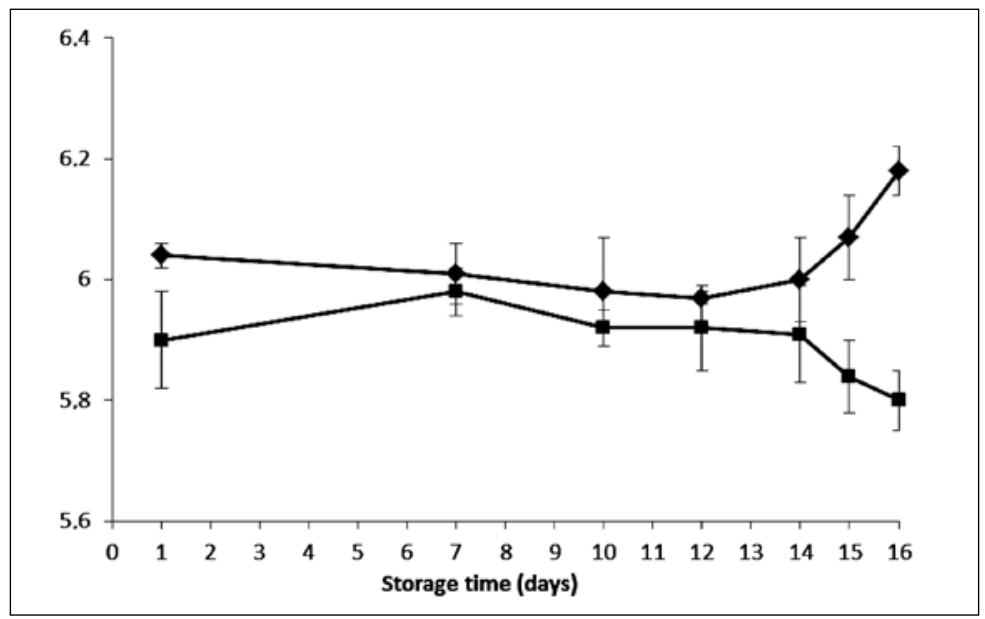

Fig. 3. pH changes in cold-smoked common carp fillets $(\bullet)$ and cold-smoked bighead carp fillets ( $\mathbf{\square})$ stored under vaccum conditions at $+3 \pm 0.5^{\circ} \mathrm{C}$.

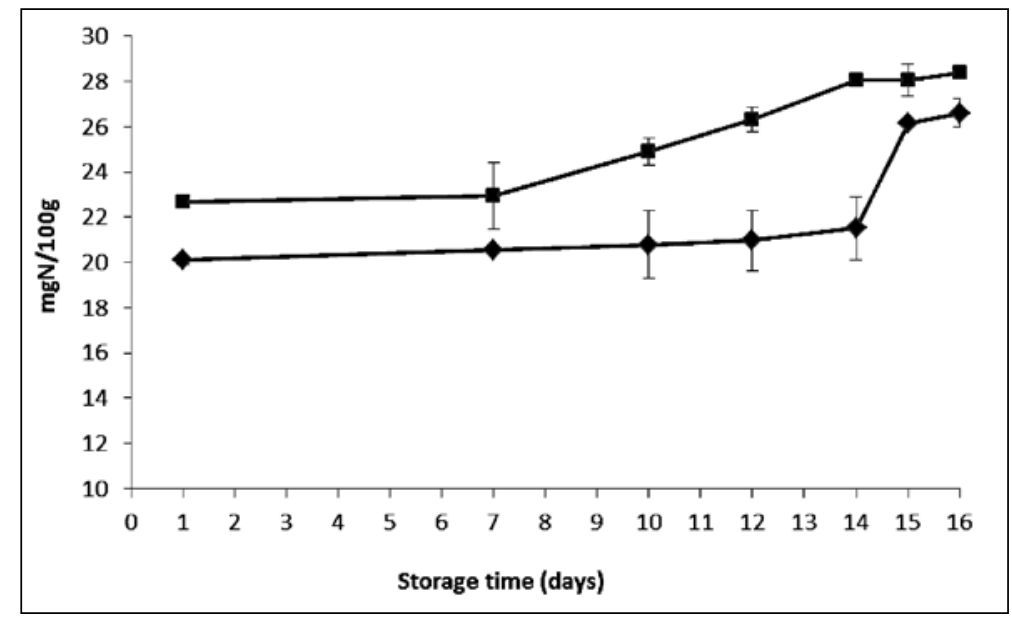

Fig. 4. TVB-N changes in cold-smoked common carp fillets $(\bullet)$ and cold-smoked bighead carp fillets ( $\square)$ stored under vaccum conditions at $+3 \pm 0.5^{\circ} \mathrm{C}$.

The results of the sensory evaluation of cold-smoked common carp fillets and coldsmoked bighead carp fillets are presented in Table 1. As the results show, all estimated sensory characteristics of common carp samples received significantly lower $(P<0.05)$ score on day 15. "Musty" odour of common carp samples detected on day 16 caused that 
odour score was below the acceptability limit of 2 . On the last day of experiment, reduced intensity of pink cream colouring of carp muscle was observed together with softened texture and surface slime. A decrease of scores of the sensory attributes of cold-smoked bighead carp fillets was observed throughout the storage period. However, all estimated sensory characteristics were within the acceptability level.

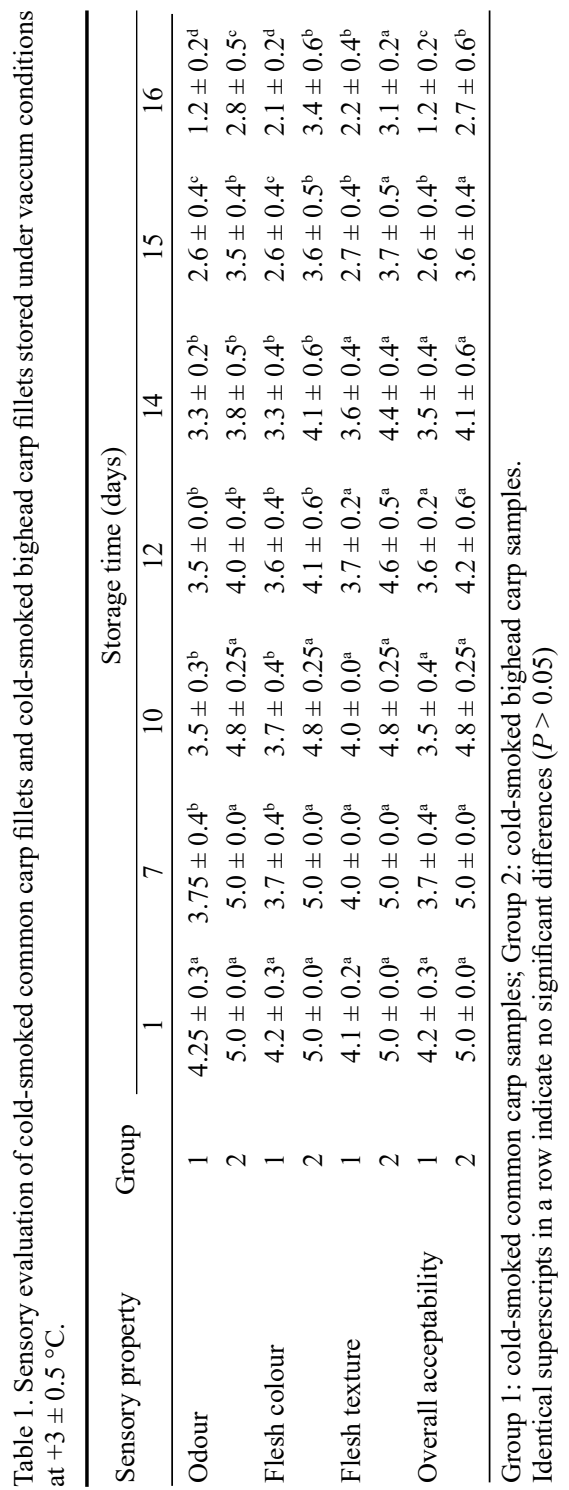

\section{Discussion}

Smoked fishery products in vacuum packs are currently well introduced at the retail level. The efficiency of vacuum in extending the shelf life of smoked fish depends on several factors, such as the fish species, fat content, initial microbial cell count and most importantly, the storage temperature. The most common reason for spoilage of smoked fish products is microbial activity. Microbial growth and the creation of products of their metabolic activity can lead to undesirable odour and taste, and the appearance of discoloration (Leroi et al. 2001).

In our research, immediately after smoking the products, the TVC values in both groups of samples were the highest compared to other examined micro-organisms. During storage a positive effect of vacuum on reduced microbial growth was observed, and these micro-organisms showed the slowest growth. Zhang et al. (2015) examined the dominant microorganisms in vacuum- and air-packaged common carp fillets. During storage they detected a decrease in TVC values in vacuum-packaged samples compared to air-packaging, which supports the results of our research. At the end of our experiment, TVC in both groups of samples had not reached the value of $7 \log \mathrm{cfu} / \mathrm{g}$, which is referred to sensory changes of products. When vacuum packaging is used, due to bacterial metabolism, carbon dioxide contents in the gaseous phase gradually increase inside the package, therefore influencing the growth of aerobic Gram-negative bacteria (Radetić et al. 2007). On the other hand, Olafsdottir et al. (2005) reported that the TVC values ranged from 7 to $8 \log \mathrm{cfu} / \mathrm{g}$ at the end of the shelf-life period of vacuum-packaged cold-smoked salmon. They suggested there was good correlation between TVC values and sensory evaluation of overall acceptability. Interestingly, the psychrotrophic viable count shows the most intensive growth in the first seven days of storage in both groups. This may be attributed to the fact that the samples were stored at a temperature very close to the temperature which is optimal for growth of these micro-organisms. From then on, the PVC values in both samples groups remained quite stable until the end of experiment. 
In our experiment, at the end of the storage period LAB were the dominant flora in the cold-smoked bighead carp samples. The dominance of these bacteria was previously reported in vacuum-packaged lightly preserved fish products stored at chilled temperature. Gomez-Guillen et al. (2009) found LAB dominating in three species of vacuum-packaged cold-smoked fish. Truelstrup Hansen et al. (1998) found the same in vacuum-packaged cold-smoked salmon. The dominance of these facultative anaerobic micro-organisms is explained by their ability to grow rapidly under anaerobic conditions at low temperatures, as well as their $\mathrm{CO}_{2}$ tolerance. According to Leroi et al. (1998), LAB counts and the general viable count can be very high even before a product was spoiled, while some vacuumpackaged cold-smoked salmon with strong off-odours can have a relatively low viable count. Paludan-Muller et al. (1998) reported that spoilage microflora for the same fish product was composed of LAB with an associated Gram-negative flora of varying levels. No relationship between any microbiological numbers and sensory changes has been found in vacuum-packaged cold-smoked fish products (Truelstrup Hansen et al. 1995; Leroi et al. 1998). Although LAB can easily cause spoilage of cold-smoked products (Lyhs et al. 1998), it is considered that these micro-organisms in vacuum-packaged food contribute to prolonged shelf-life by inhibiting the growth of other bacteria through creating lactic acid and bacteriocine (Gram and Dalgaard 2002). This characteristic of LAB can be the cause of the lower TVC values and better shelf-life of cold-smoked bighead carp samples in our experiment.

Fungi growth (mainly yeasts) on vacuum-packaged cold-smoked fish is quite common, which is confirmed by our research. Intensive growth of TYMC is recorded at the end of experiment in cold-smoked bighead carp samples compared to cold-smoked common carp samples. According to Gonzales-Rodriguez et al. (2002), fungi counts were higher in smoked trout fillets than in smoked salmon samples, although differences were not significant $(P>0.05)$. The TYMC in cold-smoked salmon in the research by Leroi et al. (1998) showed slower growth during storage at a temperature of $+8{ }^{\circ} \mathrm{C}$; their numbers remained low during the whole experimental period. Cakli et al. (2006) did not find the presence of TYMC in samples of hot-smoked trout packaged in vacuum and modified atmosphere. They concluded that the growth of yeast and mould is influenced by the strong effect of smoke and temperature during hot-smoke fish processing.

The $\mathrm{pH}$ values of cold-smoked common carp and bighead carp samples range from $5.97 \pm 0.08$ to $6.18 \pm 0.07$, and from $5.80 \pm 0.08$ to $5.98 \pm 0.06$, respectively. Based on these values, we can conclude that the $\mathrm{pH}$ values in both groups of samples were quite stable. Decreasing $\mathrm{pH}$ values in bighead carp samples at the end of experimental period can be explained by acid metabolic products created by different kinds of bacteria, lactobacilli in the first place (Truelstrup Hansen et al. 1995), which were present in the bighead carp samples in higher numbers. Moderate growth of the $\mathrm{pH}$ value of cold-smoked common carp samples at the end of the storage period may be attributed to the higher quantity of basic compounds produced by the activity of fish spoilage bacteria (Stohr et al. 2001), such as aerobic Gram-negative bacteria.

The combined total amount of ammonia(NH3), dimethylamine(DMA) and trimethylamine (TMA) in fish is called the Total Volatile Base Nitrogen (TVB-N); its content in fish meat is commonly used for spoilage estimation, and as an index for freshness of fish. Different contents of TVB-N in samples of cold-smoked common carp and bighead carp in the initial phase of experiment, may be related to different values of fish Non-Protein Nitrogen (NPN), which in turn is determined by the type of fish feeding, season of catching, fish size, as well as initial microbiological quality of fish tissue (Connell 1995). In common carp and bighead carp samples an increase of TVB-N values was observed during the storage period. Similar results have also been obtained by Ježek and Buchtova (2010) and Babić et al. (2014). Since TVB-N is produced mainly during bacterial decomposition 
of fish meat, the higher content of TVC values in cold-smoked common carp samples may cause higher increase of TVB-N values at the end of experiment. As reported by Leroi and Joffraud (2000), TVB-N was a very good quality indicator of vacuum-packaged coldsmoked salmon. Also, there was strong correlation between TVB-N and the shelf life of this product. On the other hand, Cakli et al. (2006) pointed out poor correlation between spoilage and TVB-N value in hot-smoked trout samples packaged in vacuum and modified atmosphere. The TVB-N limit from 25 to $35 \mathrm{mgN} / 100 \mathrm{~g}$ has been recommended by some researchers as an indicator for rejecting commercial whole fresh fish and processed fish products (Connell 1995).

These recommended values can be partly applied to the results of our research: (1) sensory changes were observed on cold-smoked common carp samples at TVB-N value $26.62 \pm 0.64 \mathrm{mgN} / 100 \mathrm{~g}$, while (2) cold-smoked bighead carp samples remained acceptable from sensory point of view at TVB-N value $28.38 \pm 0.18 \mathrm{mgN} / 100 \mathrm{~g}$.

Based on the sensory results, it was concluded that vacuum-packaged cold-smoked common carp samples remained acceptable for up to 15 days of storage, whereas vacuumpackaged cold-smoked bighead carp samples remained unchanged until the end of the experiment.

\section{Acknowledgements}

This work was supported by grants from the Ministry of Education, Science and Technological Development of the Republic of Serbia (project no. TR 46009)

\section{References}

Babić J, Dimitrijević M, Milijašević M, Đorđević V, Petronijević R, Grbić S, Spirić A 2014: Effect of modified atmospheric conditions and vacuum packaging on selected chemical parameters that define freshness of rainbow trout (Oncorhynchus mykiss) and carp (Cyprinus carpio). Hem Ind 68: 69-76

Cakli S, Kilinc B, Dincer T, Tolasa S 2006: Comparison of the shelf lifes of map and vacuum packaged hot smoked rainbow trout (Onchorhynchus mykiss). Eur Food Res Technol 224: 19-26

Connell JJ 1995: Control of fish quality ( $4^{\text {th }}$ edn). Fishing News Books Limited, London.

Gomez-Guillen C, Gomez-Estaca J, Gimenez B, Montero P 2009: Alternative fish species for cold-smoking process. Int J Food Sci Tech 44: 1525-1535

Gonzalez-Rodriguez MN, Sanz JJ, Santos JA, Otero A, Garcia-Lopez ML 2002: Numbers and types of microorganisms in vacuum-packed cold-smoked freshwater fish at the retail level. Int J Food Microbiol 77: 161-168

Gram L, Dalgaard P 2002: Fish spoilage bacteria - problems and solutions. Stud Environ Sci 13: 262-266

Hovda MB, Lunestad BT, Siverstvik M, Rosnes JT 2007: Characterisation of the bacterial flora of modified atmosphere packaged farmed Atlantic cod (Gadus morhua) by PCR-DGGE of conserved 16S rRNA gene regions. Int J Food Microbiol 117: 68-75

International Commission on Microbiological Specifications for Foods (ICMSF) 1998: Microorganisms in Foods 6. Microbial Ecology of Food Commodities. Blackie Academic \& Professional, Baltimore.

Ježek F, Buchtova H 2010. Shelf-life of chilled muscle tissue of the common carp (Cyprinus carpio L.) packaged in carbon monoxide enriched modified atmosphere. Acta Vet Brno 79: 117-125

Kerry JP, O'Grady MN, Hogan SA 2006: Past, current and potential utilisation of active and intelligent packaging systems for meat and muscle-based products: A review. Meat Sci 74: 113-130

Leroi F, Joffraud J, Chevalier F, Cardinal M 1998: Study of the microbial ecology of cold-smoked salmon during storage at $8{ }^{\circ} \mathrm{C}$. Int J Food Microbiol 39: 111-121

Leroi F, Joffraund JJ 2000: Salt and smoke simultaneously affect chemical and sensory quality of cold-smoked salmon during $5{ }^{\circ} \mathrm{C}$ storage predicted using factorial design. J Food Protect 63: 1222-1227

Leroi F, Joffraund JJ, Chevalier F, Cardinal M 2001: Research of quality indices for cold-smoked salmon using a stepwise multiple regression of microbiological counts and physics-chemical parameters. J Appl Microbiol 90: $578-587$

Lyhs U, Bjorkroth J, Hyytia E, Korkeala H 1998: The spoilage flora of vacuum-packaged, sodium nitrite or potassium nitrate treated, cold-smoked rainbow trout stored at $4{ }^{\circ} \mathrm{C}$ or $8{ }^{\circ} \mathrm{C}$. Int J Food Microbiol 45: $135-142$

Murcia MA, Martinez-Tome M, Nicolas MC, Vera AM 2003: Extending the shelf-life and proximate composition stability of ready to eat foods in vacuum or modified atmosphere packaging. Food Microbiol 20: 671-679

Olafsdottir G, Chanie E, Westad F, Jonsdottir R, Thalmann CR, Bazzo S, Labreche S, Marcq P, Lundby F, Haugen JE 2005: Prediction of microbial and sensory quality of cold smoked Atlantic salmon (Salmo salar) by electronic nose. J Food Sci 70: 563-574 
Paludan-Muller C, Dalgaard P, Huss HH, Gram L 1998. Evaluation of the role of Carnobacterium piscicola in spoilage of vacuum- and modified-atmosphere-packed cold-smoked salmon at $5{ }^{\circ} \mathrm{C}$. Int $\mathrm{J}$ Food Microbiol 39: 155-166

Radetić P, Milijašević M, Jovanović J, Velebit B 2007: Modified atmosphere packaging for fresh meat - Trend that lasts. Tehnologija mesa 48: 99-108

Sikorski ZE, Kolodziejska I 2002: Microbial risk in mild hot smoking of fish. Crit Rev Food Sci 42: 35-51

Stohr V, Joffraud JJ, Cardinal M, Leroi F 2001: Spoilage potential and sensory profile associated with bacteria isolated from cold-smoked salmon. Food Res Int 34: 797-806

Truelstrup Hansen L, Gill T, Huss HH 1995: Effects of salt and storage temperature on chemical, microbiological and sensory changes in cold-smoked salmon. Food Res Int 28: 123-130

Truelstrup Hansen L, Rontved SD, Huss HH 1998: Microbiological quality and shelf life of cold-smoked salmon from tree different processing plants. Food Microbiol 15: 137-150

Zhang Y, Li Q, Li D, Liu X, Luo Y 2015: Changes in the microbial communities of air-packaged and vacuumpackaged common carp (Cyprinus carpio) stored at $4{ }^{\circ} \mathrm{C}$. Food Microbiol 52: 197-204 